\title{
Extraction of some secondary metabolites \& Thin layer chromatography from different parts of Acacia farnesiana L.
}

\author{
Sanjay R. Biradar \& Bhagyashri D. Rachetti \\ Tissue Culture Research Center \\ Dept. of Botany, Shri Chhatrapati Shivaji College, Omerga - 413606, \\ Dist. Osmanabad, (MS). INDIA
}

\begin{abstract}
Acacia farnesiana L. is an Indian plant used in Ayurvedic treatment for many diseases. A qualitative analysis by thin layer chromatography \& a quantitative analysis by standard chemical protocol of secondary metabolites in the pod wall (pericarp) and seeds of the Acacia farnesiana L. has been studied. Using thin layer chromatography (TLC) different components like Alkaloids, Saponin, Flavonoids, and Terpenoides are isolated $\&$ identified. The $R f$ values of the developed spots in the different solvent systems are noted. In the quantitative analysis, alkaloids, saponins, terpenoids \& flavonoids are extracted by using the standard chemical protocol. These results may be helpful for rationale use of this plant in the modern system of health care.

Keywords: Acacia farnesiana L. TLC, Qualitative \& Quantitative analysis, Secondary metabolites.
\end{abstract}

\section{Introduction}

Ancient civilization considered plant extracts to be significant for various ailments [1]. There are about 2500000 species of higher plants in the world and most of them are not studied for their pharmacological activities [2]. More than $50 \%$ of all the drugs in the world, today, are from natural products and their derivatives. About $25 \%$ are contributed by the higher plants [3]. Acacia is the common name for the plants of the genus Acacia of the family Mimosaceae. The bark and leaves of $A$. fernesiana are crushed and boiled and is inhaled by the malarial patient [4].

In India, Acacia farnesiana $\mathbf{L}$ is known as Mulla tumma, Kampu tumma in local area and it is commonly known as Aroma and sweet acacia also. Grown throughout India, and often planted in gardens. If we see its yield, in India and other Eastern countries produce much for local use and Trees begin to flower from the third year, mainly from November to March. Acacia farnesiana L. grown throughout India, and often planted in gardens. If we see its yield, in India and other Eastern countries produce much for local use and Trees begin to flower from the third year, mainly from November to March. The bark of this plant is used as astringent and demulcent. The leaves and roots are used for medicinal purposes. Woody branches used in India as tooth brushes. The gummy roots also chewed for sore throat. The roots of this plant are also used for the antispasmodic, aphrodisiac, astringent, demulcent, diarrhea, febrifuge, rheumatism, and stimulant [5]. The plant is also used as diuretic, treat antiulcer, anti-pyritic etc. Absence of evidence on anti-diabetic activity of Acacia farnesiana let us embark on this study with an aim to scientifically prove the traditional claim of this plant [6]. Diabetes Mellitus (DM) is a major degenerative disease [7] [8] affecting at least $10 \%$ of the population, worldwide. Complications of DM include hypertension, atherosclerosis, microcirculatory disorders, retinopathy, nephropathy, neuropathy and angiopathy [9].

\subsection{Collection of materials:}

\section{Material and Methods:-}

The fresh parts of Acacia farnesiana L. were collected from Omerga Tq.Omerga, Dist. Osmanabad, Maharashtra. The plant material were properly washed with tap water and then rinsed with distilled water, dried in oven at $60^{\circ} \mathrm{C}$ until plant parts became well dried for grinding. After drying, the plant materials were ground well into fine powder.

\subsection{Preparation of ethanolic extracts (Pod wall and Seeds)}

For preparation of ethanolic extract, a modified method of Abdulrahman et.al (2004) [10] was used. The fresh parts of the plant were dried in oven and ground to fine powder with mechanical grinder. Ten gram of each plant parts was then macerated in $100 \mathrm{ml}$ of absolute ethanol for $72 \mathrm{hr}$. \& properly covered with aluminium foil \& labeled. After $72 \mathrm{hrs}$ of extraction, each extract was filtered through Whatman's filter paper no.1 separately. The filtrate was evaporated to dryness at room temperature \& store at $5^{0} \mathrm{C}$ in refrigerator.

3. Qualitative analysis by thin layer chromatography analysis:-

Extract was to begin with, checked by Thin Layer Chromatography (TLC) on analytical plates over 
silica gel. TLC was carried out to isolate the principle components that were present in most effective extracts of plant. The different solvent systems of different polarities were prepared and TLC studies were carried out to select the solvent system capable of showing better resolution.

\section{Method}

The above prepared plant extracts were applied on pre-coated TLC plates by using capillary tubes and developed in a TLC chamber using suitable mobile phase. The developed TLC plates were air dried and observed under ultra violet light UV at both $254 \mathrm{~nm}$ and $366 \mathrm{~nm}$. They were later sprayed with different spraying reagents and some were placed in hot air oven for $1 \mathrm{~min}$ for the development of color in separated bands. The movement of the analyze was expressed by its retention factor (Rf). Values were calculated for different sample.

$\mathbf{R} \boldsymbol{f}=\frac{\text { Distance travel by solute }}{\text { Distance travel by solvent }}$

\section{Detection}

Where- (Rf-Retention factor)

After drying the plates, they were exposed to Iodine vapours by placing in a chamber that was saturated with iodine vapours and also exposed to different spraying reagents. All plates were visualized directly after drying and with the help of UV at $254 \mathrm{~nm}$ and $366 \mathrm{~nm}$ in UV TLC viewer. The Rf value of the different pots that were observed was calculated [11]

\section{Quantitative analysis by extraction method:-}

The phytochemicals which are present in the of Acacia farnesiana $\mathrm{L}$. were determined and quantified by standard procedures.

\subsection{Alkaloid determination using Harborne (1973) method:-}

$5 \mathrm{~g}$ of the sample was weighed into a $250 \mathrm{ml}$ beaker and $200 \mathrm{ml}$ of $10 \%$ acetic acid in ethanol was added and covered and allowed to stand for $4 \mathrm{~h}$. This was filtered and the extract was concentrated on a water bath to one-quarter of the original volume. Concentrated ammonium hydroxide was added dropwise to the extract until the precipitation was complete. The whole solution was allowed to settle and the precipitated was collected and washed with dilute ammonium hydroxide and then filtered. The residue is the alkaloid, which was dried and weighed [12].

\subsection{Flavonoid determination by the method of Bohm and Kocipai- Abyazan (1994):-}

$10 \mathrm{~g}$ of the plant sample was extracted repeatedly with $100 \mathrm{ml}$ of $80 \%$ aqueous methanol at room Temperature. The whole solution was filtered through whatman filter paper No $42(125 \mathrm{~mm})$. The filtrate was later transferred into a crucible and evaporated into dryness over a water bath and weighed to a constant weight [13].

\subsection{Saponin determination using Obadoni and Ochuko (2001) method:-}

The method used was that of Obadoni and Ochuko (2001). $10 \mathrm{~g}$ of samples powder was put into a conical flask and $50 \mathrm{ml}$ of $20 \%$ aqueous ethanol were added. The samples were heated over a hot water bath for $4 \mathrm{~h}$ with continuous stirring at about $55^{\circ} \mathrm{C}$. The mixture was filtered and the residue reextracted with another $100 \mathrm{ml} 20 \%$ ethanol. The combined extracts were reduced to $20 \mathrm{ml}$ over water bath at about $90^{\circ} \mathrm{C}$. The concentrate was transferred into a $250 \mathrm{ml}$ separating funnel and $10 \mathrm{ml}$ of diethyl ether was added and shaken vigorously. The aqueous layer was recovered while the ether layer was discarded. The purification process was repeated. $30 \mathrm{ml}$ of n-butanol was added. The combined n-butanol extracts were washed twice with $10 \mathrm{ml}$ of $5 \%$ aqueous sodium chloride. The remaining solution was heated in a water bath. After evaporation the samples were dried in the oven to a constant weight and the Saponin content was calculated as percentage [14].

\subsection{Estimation of total Terpenoides using Ferguson (1956) method:-}

$10 \mathrm{~g}$ of plant powder were taken separately and soaked in alcohol for 24 hours. Then filtered, the filtrate was extracted with petroleum ether; the ether extract was treated as total Terpenoides [15]. 


\section{Result and Discussion}

From the earlier report knew that Acacia farnesiana was traditionally used for many diseases particularly the plant was identified and authenticated botanically. The Plant parts (pod wall and seeds) were shade dried and the coarse powder was extracted by soaking method using ethanol successively. All the extracts were concentrated under reduced pressure. The results of TLC and quantitative analysis are as follows.

\section{Thin layer chromatography}

TLC profiling of all extracts gives an impressive result that directing towards the presence of number of phytochemicals. Various phytochemicals gives different $R f$ values in different solvent system. This variation in $\mathrm{R} f$ values of the phytochemicals provides a very important clue in understanding of their polarity.

\section{TLC Alkaloid}

TLC of pod wall extract of Acacia farnesiana revealed the presence of 2 compound having $R f$ values of 0.60, 0.79 when a solvent phase of Methanol: conc. $\mathrm{NH}_{4} \mathrm{OH}$ (17:3) was used. TLC of seed extract of Acacia farnesiana revealed the presence of 1 compounds having $\mathrm{R} f$ values of 0.63 when a solvent phase of Methanol: conc. $\mathrm{NH}_{4} \mathrm{OH}(17: 3)$ was used.

\section{TLC Flavonoid}

TLC of pod wall extract of Acacia farnesiana revealed the presence of 3 compounds having R $f$ values of $0.16,0.30,0.63$ when a solvent phase of Chloroform: methanol (18:2) was used. TLC of seed extract of Acacia farnesiana revealed the presence of 2 compounds having $\mathrm{R} f$ values of $0.11,0.55$ when a solvent phase of Chloroform: methanol (18:2) was used.

\section{TLC Saponin}

TLC of pod wall extract of Acacia farnesiana revealed the presence of 1 compound having $\mathrm{R} f$ values of 0.86 when a solvent phase of Chloroform: glacial acetic acid: methanol: water $(6: 2: 1: 1)$ was used. TLC of seed extract of Acacia farnesiana revealed the presence of 1 compounds having $\mathrm{R} f$ values of 0.85 when a solvent phase of Chloroform: glacial acetic acid: methanol: water (6:2:1:1) was used.

\section{Photo plates: Separation of compound by Using different solvent system for thin layer chromatography of} podwall \& seed of $A$. fernesiana

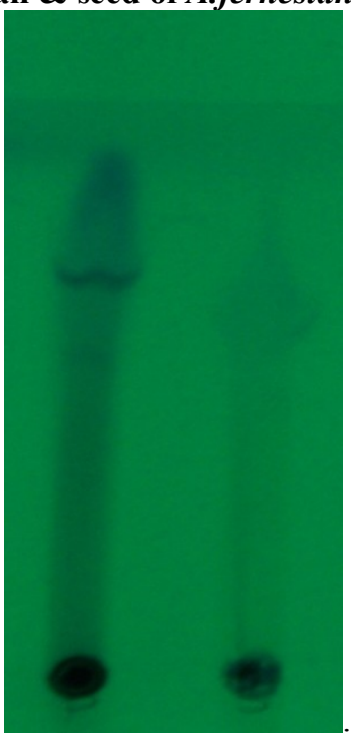

1

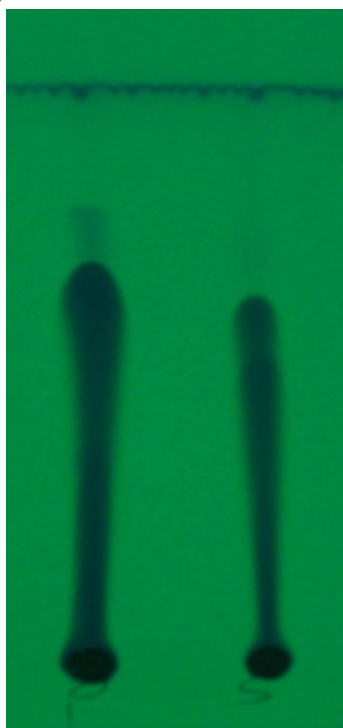

2

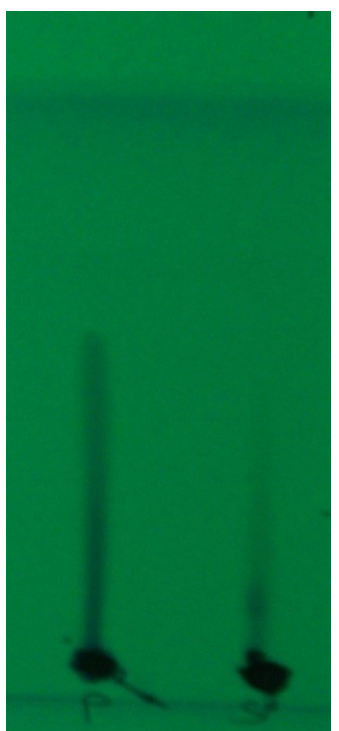

3

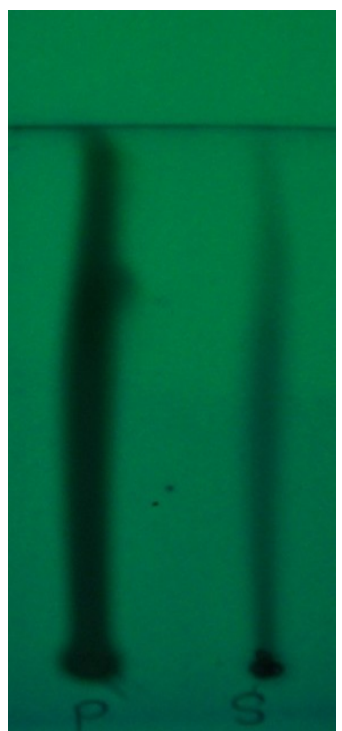

4

\section{Photoplate: 1.TLC of Alkaloids $\quad$ 2.TLC of Flavonoid $\quad 3 . T L C$ of Terpenoids 4.TLC of Saponin}

Table 1:- Phytochemical Analysis of different parts of Acacia farnesiana L. by Thin layer chromatography.

\begin{tabular}{|c|c|c|c|c|}
\hline Chemical name & Solvent system & Plant part & $\mathbf{R} f$ values & Spray Reagent \\
\hline \multirow[t]{2}{*}{ Alkaloids } & \multirow{2}{*}{$\begin{array}{l}\text { Methanol: } \\
\text { conc. } \\
\mathrm{NH}_{4} \mathrm{OH}(17: 3)\end{array}$} & Pod wall & $0.60,0.79$ & \multirow[t]{2}{*}{ Mayer's reagent } \\
\hline & & Seed & 0.63 & \\
\hline \multirow[t]{2}{*}{ Flavonoid } & \multirow[t]{2}{*}{$\begin{array}{l}\text { Chloroform: } \\
\text { methanol(18:2) }\end{array}$} & Pod wall & $0.16,0.30,0.63$ & \multirow[t]{2}{*}{ UV light } \\
\hline & & Seed & $0.11,0.55$ & \\
\hline
\end{tabular}




\begin{tabular}{|c|c|c|c|c|}
\hline \multirow[t]{2}{*}{ Saponins } & \multirow{2}{*}{$\begin{array}{l}\text { Chloroform: glacial } \\
\text { acetic acid: } \\
\text { methanol: } \\
\text { water( } 6: 2: 1: 1)\end{array}$} & Pod wall & 0.86 & \multirow[t]{2}{*}{ Iodine vapours } \\
\hline & & Seed & 0.85 & \\
\hline \multirow[t]{2}{*}{ Terpenoides } & $\begin{array}{l}\text { Benzene : Ethyl acetate } \\
(1: 1)\end{array}$ & Pod wall & 0.67 & \multirow[t]{2}{*}{$\begin{array}{llll}10 \% & \mathrm{H}_{2} \mathrm{SO}_{4} & \& & \mathrm{UV} \\
\text { light } & & & \end{array}$} \\
\hline & & Seed & 0.45 & \\
\hline
\end{tabular}

\section{TLC Terpenoid}

TLC of pod wall extract of Acacia farnesiana revealed the presence of 1 compound having R $f$ values of 0.67 when a solvent phase of Benzene: Ethyl acetate (1:1) was used. TLC of seed extract of Acacia farnesiana revealed the presence of 1 compounds having $\mathrm{R} f$ values of 0.45 when a solvent phase of Benzene: Ethyl acetate (1: 1) was used.

\section{Quantitative analysis:}

Table 2:- Quantitative analysis of Acacia farnesiana.

\begin{tabular}{|l|l|l|l|l|l|l|l|l|l|l|l|}
\hline $\begin{array}{l}\text { Plant } \\
\text { part }\end{array}$ & $\begin{array}{l}\text { Fresh } \\
\text { wt. } \\
\text { In gm }\end{array}$ & Dry wt. & $\begin{array}{l}\text { DM } \\
{[\%]}\end{array}$ & $\begin{array}{l}\text { Alk. } \\
\text { In gm }\end{array}$ & $\begin{array}{l}\text { Alk. } \\
{[\%]}\end{array}$ & $\begin{array}{l}\text { Flav. } \\
\text { In gm }\end{array}$ & $\begin{array}{l}\text { Flav. } \\
{[\%]}\end{array}$ & $\begin{array}{l}\text { Terp. } \\
\text { In gm }\end{array}$ & $\begin{array}{l}\text { Terp. } \\
{[\%]}\end{array}$ & $\begin{array}{l}\text { Sapo. } \\
\text { In gm }\end{array}$ & $\begin{array}{l}\text { Sapo. } \\
{[\%]}\end{array}$ \\
\cline { 5 - 13 } & Extrac. & & Extrac. & & Extrac. & & Extrac. & \\
\hline $\begin{array}{l}\text { Pod } \\
\text { wall }\end{array}$ & 60.33 & 56.70 & 93.98 & 0.70 & 1.23 & 3.53 & 6.22 & 1.95 & 3.43 & 0.68 & 1.19 \\
\hline Seed & 61.54 & 58.13 & 94.45 & 0.02 & 0.034 & 0.88 & 1.51 & 0.25 & 0.43 & 0.54 & 0.92 \\
\hline
\end{tabular}

Note : DM \% - Dry matter percentage, Alk- Alkoloid, Flav-Flavonoid, Terp- Terpenoid, Sapo- Saponin

Based upon the preliminary phytochemical test Quantitative determination phytoconstituents were carried out for the powdered plant material by various standard methods and found that alkaloid $0.7 \mathrm{gm}$ and 0.02 $\mathrm{gm}$ in pod wall and seed respectively, flavonoids $3.53 \mathrm{gm}$ and $0.88 \mathrm{gm}$ in pod wall and seed respectively and saponin $0.68 \mathrm{gm}$ and $0.54 \mathrm{gm}$ in pod wall and seed respectively and terpenoids $1.95 \mathrm{gm}$ and $0.25 \mathrm{gm}$ in pod wall and seed respectively.

\section{Conclusion}

In the present study pod wall and seed showed the presence of bioactive compound such as alkaloids, flavonoids, terpenoids, saponins,etc . This study also leads to the further research in the way of isolation and identification of the active compound from the pod wall and seed of Acacia farnesiana using chromatographic and spectroscopic techniques.

\section{Acknowledgement}

Author Dr. Sanjay R. Biradar is grateful thanks to Principal of Shri Chhatrapati Shivaji College, Omerga, Dist. Osmanabad, (M.S.), India for providing all necessary facilities and encouragement for the present research work.

\section{References:-}

[1]. Grabely S, Thiericke R (1999). Bioactive agents from natural sources: trends in discovery and application. Adv. Biochem. Eng. Biotech., 64: 101-154.

[2]. Jeevam RA, Bhakshu L Venkata R (2004). In vitro antimicrobial activity of certain medicinal plants from Eastern Ghats, India, used for skin diseases. J. Ethnopharm., 90: 353-357.

[3]. Cragg GM, Newman DJ (2005). Biodiversity: A continuing source of novel drug leads. Pure. Appl. Chem., 77(1): 7-24.

[4]. Bora U, Sahu A, Saikia AP, Ryakala VK, Goswami P (2007). Medicinal plants used by the people of Northeast India for curing Malaria. Phytother. Res., 21: 800-804.

[5]. Duke, J.A. 1981a. Handbook of legumes of world economic importance. Plenum Press. NewYork.

[6]. R. Bino Kingsley,S. Aravinth Vijay Jesuraj, P. Brindha,A. Subramoniam, Atif M,(2013) International Journal of PharmTech Research CODEN (USA): IJPRIF ISSN : 0974-4304,

[7]. King H, Auberti RE, Herman WH. Global burden of diabetes, 1995-2025: prevalence, numerical estimates, and projections. Diabetes Care 1998;21:1414-1431.

[8]. Ogbonnia SO, Odimegwa JI, Enwaru VN. Evaluation of hypoglycemic and hypolipidemic effects of ethanolic extracts of Treculia Africana Decne and Bryophyllum pinnatum Lam. And their mixture on streptozotozin (STZ) - induced diabetic rats. African Journal of Biotechnology.2008;7(15):2535-2539.

[9]. Edem DO. Hypoglycemic effects of ethanol extracts of alligator pear seed in rats. European Journal of Scientific Research 2009; 33:669-678.

[10]. Abdulrahman F, Inyang SI, Abbah J, Binda L, Amos S, Gamaniel K (2004). Effect of aqueous leaf extracts of Irvingia gabonesis on gastrointestinal tracts of rodents. India J. Exp. Biol. 42:787-791.

[11]. Harborne JB, Phytochemical methods: A Guide to Modern techniques of plants Analysis. Chapman and Hall London, UK. 1998.

[12]. Harborne JB. Phytochemical methods, London. Chapman and Hall, Ltd. 1973; 49-188. 
[13]. Boham BA and Kocipai-Abyazan R. "Flavonoids and condensed tannins from leaves of Hawaiian Vaccinium vaticulatum and V. calycinium” Pacific Science (1974) 48: 458-463.

[14]. Obdoni BO and Ochuko PO. "Phytochemical studies and comparative efficacy of the crude extracts of some Homostatic plants in Edo and Delta States of Nigeria" Global J. Pure Appl. Sci. (2001) 8: 203-208.

[15]. Ferguson NM. A Text book of Pharmacognosy. Mac Milan Company, New Delhi, 1956, 191. 